\title{
The effects of inulin supplementation of diets with or without hydrolysed protein sources on digestibility, faecal characteristics, haematology and immunoglobulins in dogs
}

\author{
A. Verlinden, M. Hesta, J. M. Hermans and G. P. J. Janssens* \\ Laboratory of Animal Nutrition, Faculty of Veterinary Medicine, Ghent University, Heidestraat 19, B-9820 Merelbeke, Belgium
}

(Received 1 September 2005 - Revised 12 June 2006 - Accepted 16 June 2006)

\begin{abstract}
Dogs with food allergy are often treated by giving a diet with hydrolysed protein sources. Prebiotics might also be successful in prevention and treatment of allergic disease through their effect on the colonic microflora, analogous to studies on probiotics in allergic children. The present study was set up to investigate the effect of supplementing inulin (IN) to commercial hypoallergenic dog diets on apparent nutrient digestibility, faecal characteristics, haematology and Ig in dogs. Supplementation of $3 \%$ IN did not affect faecal $\mathrm{pH}$, food and water intake and urine production. Compared with the intact protein diet with a limited number of ingredients $(\mathrm{L})$, the diet with a hydrolysed protein source $(\mathrm{H})$ resulted in an increased water intake $(P<0.001)$, which could be due to the osmotic effect of free amino acids. Faeces production was increased by IN due to increased faecal moisture content. Increased faeces production on the H diet was mainly due to a higher DM excretion. Subsequently, the apparent digestibility coefficient (ADC) of DM was lower in the H diet group. A similar result was noted for ADC of diethyl ether extract and crude ash. The ADC of crude protein was higher in the $\mathrm{H}$ diet group, whereas IN decreased the ADC of crude protein. Differences in the ADC of crude protein among the different diets disappeared after correction for a higher faecal biomass, except for the dogs fed the $L+$ IN diet. Total faecal $\operatorname{IgA}$ concentrations were lower in the $\mathrm{H}$ group $(P<0.05)$ because of lower antigenic stimulation of hydrolysed protein, which implies that hydrolysed protein is really hypoallergenic. The present study indicates that the use of hydrolysed protein diets for canine food allergy treatment can affect digestibility and that combination with IN affected apparent protein digestibility but not IgA response.
\end{abstract}

Digestibility: Dogs: Food allergy: Hydrolysed protein: Prebiotics

\begin{abstract}
Dogs with food allergy are treated by giving a diet without the offending food component, which requires the feeding of a diet with a novel protein source. Commercial 'hypoallergenic' diets with a limited number of ingredients are commonly recommended because they enhance the owner's cooperation and the feeding of a nutritional balanced food is assured, contrary to most home-made diets (Roudebush \& Cowell, 1992). However, long-term treatment of food-allergy patients on most commercial hypoallergenic foods is only effective in 70$80 \%$ (Jeffers et al. 1991; Roudebush \& Schick, 1994). Because of the enhanced complexity of commercial food, searching 'novel' protein sources is not easy. In analogy with the use of hydrolysed formulas for food-allergy treatment and prevention in infants, diets with hydrolysed protein sources have also been developed for dogs and cats. Cleaving peptide bonds affects the secondary and tertiary structure of the protein, which may give totally different characteristics to the hydrolysate compared with the intact protein (Boumans, 2001). Increased osmolarity, altered solubility and emulsifying properties, improvement of digestibility, reduction of protein allergenicity and changes in taste, colour and smell are possible. Hydrolysis of protein may influence the nutritional value of the protein in four ways: (1) Terminal amino acids
\end{abstract}

are split up from peptides by exopeptidases. Hydrolysed protein contains more terminal amino acids per unit protein, which supposes a higher absorption of amino acids; (2) The amount of di- and tripeptides and free amino acids may exceed the direct absorption capacity; (3) Hydrolysis by heat treatment may increase Maillard reaction products that cannot be absorbed; (4) The choice of specific protein sources can also influence protein digestibility. Protein digestibility is important in dogs because of the high protein requirements, but also in disease states such as renal and liver insufficiency and food intolerance or food allergy. Moreover, food allergy often occurs in young animals (higher protein requirements), whereas commercial hypoallergenic foods often have a lower protein content. Another important issue is the problem of faecal odour, which correlates with protein digestibility (Hesta et al. 2003). To our knowledge there are currently no data available concerning the nutritional value of hydrolysed protein diets in dogs.

Probiotics are defined as live microbial food ingredients beneficial to health. Probiotics have a potential anti-allergic effect because they can alter antigenic properties of allergens by proteolysis, change the pattern of cytokine secretion, stimulate $\operatorname{IgA}$ secretion and/or restore gut permeability (Isolauri, 
2001). Probiotics have successfully been used in the prevention and treatment of allergic disease in infants (Isolauri, 2001; Viljanen et al. 2005).

Prebiotics are indigestible components of the food that beneficially affect the host's health by selectively stimulating the growth and/or activity of one or a limited number of bacteria in the colon (Gibson \& Roberfroid, 1995). It can be assumed that the consumption of prebiotics, through their effects on the colonic microflora, will have a similar effect as probiotics on immune function. In term and preterm infants, the bifidogenic effect of a mixture of long-chain inulin (IN) and galacto-oligosaccharides has already been demonstrated (Moro et al. 2005; Veereman-Wauters, 2005). IN is a prebioticum used in human (Niness, 1999) and pet (Flickinger \& Fahey, 2002) nutrition.

In the present experiment, the influence of IN supplementation to commercial hypoallergenic dog diets on apparent nutrient digestibility, faecal characteristics, haematology and Ig was investigated in the dog.

\section{Materials and methods}

\section{Animals and experimental design}

The study was designed as a $4 \times 4$ Latin-square design with four replicates during four consecutive periods. Sixteen adult beagle dogs $(2-11$ years; $6-15 \mathrm{~kg}$ ) were divided into four groups in order to test the influence of IN supplementation to two different hypoallergenic foods. It was taken into account that all groups had similar average body weight and age distribution. In each period, a $21 \mathrm{~d}$ feed adaptation period preceded a $5 \mathrm{~d}$ total faecal collection period. At day 16 of the adaptation period, the dogs were moved from their kennel to a digestibility cage for adaptation of their metabolism and intestinal transit time. Fresh faecal samples were obtained on two consecutive days before moving the dogs to digestibility cages. Urine and faeces were collected separately. Following the collection period, the dogs were placed in their usual kennel with outdoor access. Housing and experimental procedures were agreed by the Ethical Committee of the Faculty of Veterinary Medicine of the Ghent University
(Belgium; EC 2004/60). All dogs received regular vaccinations and were treated for endoparasites (Panacur ${ }^{\circledR}$, $50 \mathrm{mg} / \mathrm{kg}, 3$ consecutive days) before the start of the study. At the start of the study and on day 24 of each period a general clinical examination was performed.

\section{Diets and feeding}

The dogs were fed a hypoallergenic diet containing a hydrolysed protein source $(\mathrm{H})$ (Hill's z/d ultra, allergen-free) or intact protein with limited ingredient composition (L) (Hill's $\mathrm{d} / \mathrm{d}$ with duck and rice). The dry food diets were ground and supplemented with 0 or $3 \%$ IN (Raftifeed $\circledR$ ips, DP 2-60; Orafti, Tienen, Belgium). Although commercial dog feeds contain lower supplementation rates, a $3 \%$ IN supplementation was chosen to study the possible immune-enhancing effect of IN without negative effects on faecal consistency, which occur at higher supplementation rates (Hesta, 2003). The hypoallergenic diets were chosen because they had a similar nutrient composition, although they differed in ingredients (Table 1). The crude protein content of the $\mathrm{H}$ diet was higher than the L diet, while total dietary fibre, insoluble dietary fibre and $\mathrm{N}$-free extract were slightly lower. The foods were fed in one meal at 08.00 hours, near individual maintenance energy requirements estimated at $450 \mathrm{~kJ}$ metabolisable energy $/ \mathrm{kg}^{0.75}$ and $650 \mathrm{~kJ}$ metabolisable energy $/ \mathrm{kg}^{075}$ for dogs older than 7 years and younger than 3 years respectively, to maintain optimal body weight. Drinking water was available ad libitum. Food and water intake were monitored daily during the collection period. The dogs were weighed weekly during the adaptation periods and at the start and end of the collection period.

\section{Sample collection and handling}

During the collection period, daily faecal output was collected at 08.00 hours, scored by the same individual for faecal consistency (1 diarrhoea; 2 poor quality, moist and poorly formed; 3 good quality, slightly moist; 4 well formed, easy to pick up, left no marks; 5 hard, crumbly faeces), immediately weighed and stored at $-20^{\circ} \mathrm{C}$ until further processing. At the end of

Table 1. Composition of the diets (chemical analysis)§

\begin{tabular}{|c|c|c|c|c|c|c|c|c|}
\hline \multirow{3}{*}{ Diet... } & \multicolumn{4}{|c|}{$\mathrm{H}$ diet $^{*}$} & \multicolumn{4}{|c|}{$\mathrm{L}$ diet $†$} \\
\hline & \multicolumn{2}{|c|}{$\mathrm{H}-\mathrm{IN}$} & \multicolumn{2}{|c|}{$\mathrm{H}+\mathrm{IN}$} & \multicolumn{2}{|c|}{$L-I N$} & \multicolumn{2}{|c|}{$L+I N$} \\
\hline & $\% \mathrm{DM}$ & $\mathrm{g} / \mathrm{MJ}$ & $\% \mathrm{DM}$ & $\mathrm{g} / \mathrm{MJ}$ & $\%$ DM & $\mathrm{g} / \mathrm{MJ}$ & $\%$ DM & $\mathrm{g} / \mathrm{MJ}$ \\
\hline DM on as-fed basis & $91 \cdot 1$ & $55 \cdot 5$ & $91 \cdot 0$ & $55 \cdot 4$ & $91 \cdot 7$ & $54 \cdot 3$ & $91 \cdot 8$ & $54 \cdot 3$ \\
\hline Crude protein & 18 & $11 \cdot 0$ & $18 \cdot 5$ & $10 \cdot 7$ & 14.4 & 8.5 & $14 \cdot 0$ & $8 \cdot 3$ \\
\hline Diethyl ether extract & 12 & $7 \cdot 3$ & 12 & $7 \cdot 3$ & $12 \cdot 5$ & $7 \cdot 4$ & $12 \cdot 2$ & $7 \cdot 2$ \\
\hline Crude ash & $5 \cdot 6$ & $3 \cdot 4$ & $5 \cdot 4$ & $3 \cdot 3$ & $5 \cdot 6$ & $3 \cdot 3$ & 5.5 & $3 \cdot 3$ \\
\hline Total dietary fibre & 3.4 & $1 \cdot 7$ & 2.6 & $1 \cdot 3$ & $4 \cdot 7$ & 2.4 & $5 \cdot 1$ & 2.6 \\
\hline Soluble dietary fibre & nd & nd & nd & nd & nd & nd & nd & nd \\
\hline Insoluble dietary fibre & 2.4 & $1 \cdot 2$ & $2 \cdot 8$ & 1.4 & 4.6 & $2 \cdot 3$ & $5 \cdot 1$ & $2 \cdot 6$ \\
\hline Metabolisable energy (kJ/100 g DM) & $1642 \ddagger$ & & 1594 & & $1690 \ddagger$ & & 1640 & \\
\hline
\end{tabular}

H, hydrolysed protein; L, intact protein; IN, $3 \%$ inulin; nd; not detectable.

*Ingredients of Hill's canine z/d ultra, allergen-free: maize starch; hydrolysed chicken liver; vegetable oil; powdered cellulose; hydrolysed chicken; glyceryl monostearate; DL-methionine; taurine; ethoxyquin (a preservative); minerals; vitamins.

†Ingredients of Hill's canine d/d duck and rice: Brewer's rice; duck by-products; rice protein concentrate; pork fat; vegetable oil; sucrose; powdered cellulose; glyceryl monostearate; taurine; ethoxyquin (a preservative); minerals; vitamins.

‡Data from manufacturer.

$\S$ For details of diets and procedures, see p. 937. 
the collection period, faeces were thawed, homogenised, lyophilised and sampled for chemical analysis. Fresh faecal samples (within $30 \mathrm{~min}$ of defecation) were taken for $\mathrm{pH}$ and faecal microbial protein determination. Before the dogs were put in the metabolism cages, a fresh faecal sample was taken rectally for total faecal $\operatorname{IgA}$ measurement and immediately stored at $-80^{\circ} \mathrm{C}$ until further processing. A blood sample was collected via jugular puncture on day 24 of each period. Of each sample, $10 \mathrm{ml}$ blood was collected into non-heparinised tubes for determination of serum total $\mathrm{Ig} \mathrm{A}, \operatorname{IgE}$, $\operatorname{IgM}$ and $\operatorname{IgG}$ concentration. Another $10 \mathrm{ml}$ blood was collected in a vacuum tube containing EDTA for complete blood count (erythrocytes, $\mathrm{Hb}$, packed cell volume, platelets, total leucocytes, neutrophils, eosinophils, basophils, lymphocytes and monocytes).

\section{Chemical analyses}

Diets and faeces were analysed for proximate analysis (crude protein, diethyl ether extract, total dietary fibre, soluble dietary fibre, insoluble dietary fibre and crude ash). Microbial faecal protein was determined as described by Hesta et al. (2003); bacterial $\mathrm{N}$ was estimated as soluble $\mathrm{N}$ according to the method of Mason (1969), using SDS to dissolve the bacterial material. Faecal $\mathrm{pH}$ was measured electrometrically after dilution with distilled water (1:10; wt/vol).

\section{Immunological analyses}

For the determination of total faecal IgA concentrations, approximately $1-2 \mathrm{~g}$ faeces (wet weight) was contained in a tube and extraction buffer (PBS solution, 20\% FCS (Integro, Dieren, The Netherlands), $1 \%$ penicillin-streptomycin (Invitrogen, Merelbeke, Belgium), 0.2\% Tween-20 (Merck, Hohenbrunn, Germany)) was added to reach a dilution of 1:2. Samples were thoroughly homogenised by manual shaking and vortexing. Afterwards, faecal suspensions were put in a warm water pool of $56^{\circ} \mathrm{C}$ for $30 \mathrm{~min}$ and centrifuged at $9390 \mathrm{~g}$ for $30 \mathrm{~min}$ at $4^{\circ} \mathrm{C}$. The supernatant fraction was transferred to a $1.5 \mathrm{ml}$ Eppendorf tube and centrifuged a second time. This supernatant fraction was again transferred and stored at $-20^{\circ} \mathrm{C}$. A commercial ELISA was used to quantify total faecal $\operatorname{IgA}$ using goat anti-dog antibody (Dog IgA ELISA Quantification Kit ${ }^{\circledR}$; Bethyl Laboratories Inc., Montgomery, TX, USA). After blood was collected in non-heparinised evacuated tubes, samples were centrifuged at $2060 \mathrm{~g}$ for $20 \mathrm{~min}$ at $4^{\circ} \mathrm{C}$ and the serum collected. Total serum IgA, IgE, IgM and IgG concentrations were determined using commercial kits using goat anti-dog antibody for $\operatorname{Ig} \mathrm{A}, \operatorname{IgM}$ and $\operatorname{IgE}$, and sheep anti-dog antibody for IgG (Dog IgG ELISA Quantification Kit ${ }^{\circledR}$ ).

\section{Calculations and statistical analysis}

Apparent digestibility coefficients (ADC) of nutrients (crude protein, diethyl ether extract, $\mathrm{N}$-free extract and crude ash) were calculated by using the total collection method. All statistical analyses were performed using SPSS 12.0 (SPSS Inc., Chicago, IL, USA). Normally distributed parameters were subjected to variance analysis in which food, period and dog were defined as main factors. For IgA, IgE, IgM and IgG concentrations a log-transformation was performed to obtain normally distributed values. Parameters that had no normal distribution (faecal score, body condition score, total eosinophils, total basophils and basophils) were analysed with a non-parametric Friedman test.

\section{Results}

\section{Food and water intake and urine production}

The dogs remained healthy during the experiment and acceptance of diet was good. Supplementation of IN had no influence on food and water intake or urine production (Table 2). The dogs consumed significantly more water in the $\mathrm{H}$ group compared with the $\mathrm{L}$ group $(P<0.001)$. There was also a trend for a higher urine production in the $\mathrm{H}$-fed dogs $(P=0.069)$.

\section{Faecal characteristics}

Faecal DM concentration was significantly decreased by supplementation of IN on both diets $(P=0.001)$ (Table 3). Compared with the L group, faecal output was significantly higher in the $\mathrm{H}$ group, due to higher faecal DM content $(P<0.001)$. Supplementing IN increased faecal output because of increased moisture content, but the effect was only significant in the L group. There were no significant differences in faecal $\mathrm{pH}$ among treatments. Faecal consistency score was lower with IN, in agreement with the higher faecal moisture amount following IN supplementation.

\section{Apparent nutrient digestibility coefficients and faecal estimated bacterial protein content}

Table 4 presents ADC of the different nutrients and faecal estimated bacterial protein content (FEBPC). ADC of crude protein was higher in the $\mathrm{H}$ group compared with the $\mathrm{L}$ group $(P<0.001)$. Supplementation of IN decreased the ADC of

Table 2. Average water and food intake and urine production $\dagger$

(Mean values with their standard errors for sixteen dogs)

\begin{tabular}{lllllrrr}
\hline Diet & $\mathrm{H}-\mathrm{IN}$ & $\mathrm{H}+\mathrm{IN}$ & $\mathrm{L}-\mathrm{IN}$ & $\mathrm{L}+\mathrm{IN}$ & SEM total & $P$ & $n^{\star}$ \\
\hline Water intake $(\mathrm{ml} / \mathrm{d})$ & $385.3^{\mathrm{b}}$ & $384.4^{\mathrm{b}}$ & $207.8^{\mathrm{a}}$ & $218.0^{\mathrm{a}}$ & 19.87 & $<0.001$ & 4 \\
Food intake $(\mathrm{g} / \mathrm{d})$ & 247.6 & 246.4 & 247.8 & 252.2 & 9.74 & 0.890 & 4 \\
Urine production $(\mathrm{ml} / \mathrm{d})$ & 710.7 & 573.7 & 507.3 & 500.6 & 30.18 & 0.069 & 4 \\
\hline
\end{tabular}

$\mathrm{H}$, hydrolysed protein; L, intact protein; IN, $3 \%$ inulin.

${ }^{\mathrm{a}, \mathrm{b}}$ Mean values within a row with unlike superscript letters were significantly different $(P<0.05)$

${ }^{*}$ Number of repetitions within a treatment.

†For details of diets and procedures, see p. 937. 
Table 3. Faecal characteristicsł

(Mean values with their standard errors for sixteen dogs)

\begin{tabular}{|c|c|c|c|c|c|c|c|}
\hline Diet & $\mathrm{H}-\mathrm{IN}$ & $\mathrm{H}+\mathrm{IN}$ & $L-I N$ & $\mathrm{~L}+\mathrm{IN}$ & $\mathrm{SEM}_{\text {total }}$ & $P$ & $n^{\star}$ \\
\hline Faecal DM (\%) & $40 \cdot 8^{b}$ & $36 \cdot 7^{\mathrm{a}}$ & $40 \cdot 3^{b}$ & $34 \cdot 7^{\mathrm{a}}$ & 0.66 & 0.001 & 4 \\
\hline Faecal output (g/d) & $70 \cdot 8^{\mathrm{b}, \mathrm{c}}$ & $75 \cdot 4^{c}$ & $53 \cdot 0^{a}$ & $65 \cdot 8^{b}$ & 9.04 & $<0.001$ & 4 \\
\hline Faecal DM (g/d) & $28 \cdot 5^{\mathrm{b}}$ & $27 \cdot 1^{\mathrm{b}}$ & $21 \cdot 1^{a}$ & $22 \cdot 1^{a}$ & 2.51 & $<0.001$ & 4 \\
\hline Faecal moisture (g/d) & $41 \cdot 7^{b}$ & $48 \cdot 5^{b}$ & $32 \cdot 0^{\mathrm{a}}$ & $43 \cdot 6^{b}$ & 7.55 & $<0.001$ & 4 \\
\hline Faecal score & 2.9 & $2 \cdot 6$ & 2.9 & $2 \cdot 8$ & 0.04 & 0.012 & 4 \\
\hline Faecal pH & $7 \cdot 1$ & $6 \cdot 9$ & $6 \cdot 9$ & $6 \cdot 7$ & 0.06 & 0.160 & 4 \\
\hline
\end{tabular}

$\mathrm{H}$, hydrolysed protein; L, intact protein; IN, $3 \%$ inulin.

${ }_{a, b, c}$ Mean values within a row with unlike superscript letters were significantly different $(P<0.05)$.

* Number of repetitions within a treatment.

† Score of 1 diarrhoea; 3 good quality, slightly moist; 5 hard, crumbly faeces.

fFor details of diets and procedures, see p. 937.

crude protein in dogs fed the L diet. FEBPC expressed on DM basis, percentage of faecal crude protein or percentage of crude protein intake, was significantly lower in the H group compared with the L group. Following IN supplementation, FEBPC expressed on DM basis and crude protein intake was only increased in the L group. Differences in the ADC of crude protein between the different diets disappeared after correction for FEBPC, except for the dogs fed the L + IN diet. The apparent digestibility of other nutrients (DM, diethyl ether extract, crude ash) were significantly higher in the L groups compared with the $\mathrm{H}$ groups. Within the $\mathrm{H}$ groups, IN supplementation significantly improved apparent DM and crude ash digestibility.

\section{Haematology}

Average values of all haematology parameters were within reference values (Table 5). The number of total leucocytes was significantly higher on the L + IN diet compared with the other diets $(P=0 \cdot 044)$.

\section{Immunoglobulins}

Log-transformed total serum IgA, IgE, IgM and IgG concentrations were not different among treatments (Table 6). The ratios of total faecal $\mathrm{IgA}(\mathrm{mg} / \mathrm{ml})$ to dry faecal weight per d or total faecal output were significantly lower for the $\mathrm{H}$ compared with the $\mathrm{L}$ diet $(P=0.017$ and $P=0.045$, respectively). Supplementation of IN had no significant effect.

\section{Discussion}

Food consumption did not differ among the four diets. Yet, it is known that enhanced osmolarity, associated with the degree of hydrolysis (percentage of peptide bonds cleaved), may cause a bitter taste in diets with hydrolysed protein (Boumans, 2001). The exact degree of hydrolysis of the diet in the present study was not determined, but according to the manufacturer's label, protein is hydrolysed to a molecular weight less than $6 \mathrm{kDa}$ without the presence of any intact protein. A clinical study trial conducted with the same commercial hydrolysed protein diet reports a good or excellent palatability in $76.2 \%$ of the dogs (Loeffler et al. 2004).

The increase in water consumption in dogs fed the $\mathrm{H}$ diet can be caused by the osmotic effect of free amino acids in the gut. Increased osmolarity following protein hydrolysis is caused by an increased number of ion groups (Boumans, 2001) and may draw large quantities of water into the small intestine, causing diarrhoea and possible dehydratation (Mahmoud, 1994). An increase in water consumption by dogs fed hydrolysed protein has not yet been described in the literature.

\section{Faecal characteristics}

The cause for a higher faecal output following IN supplementation in the present study was an increase in faecal water, whereas the higher faecal output in the $\mathrm{H}$ fed $\operatorname{dogs} v$. the L-fed dogs was rather due to a higher

Table 4. Apparent nutrient digestibility coefficients (ADC) and faecal estimated bacterial protein content (FEBPC)† (Mean values with their standard errors for sixteen dogs)

\begin{tabular}{|c|c|c|c|c|c|c|c|}
\hline Diet & $\mathrm{H}-\mathrm{IN}$ & $\mathrm{H}+\mathrm{IN}$ & $\mathrm{L}-\mathrm{IN}$ & $\mathrm{L}+\mathrm{IN}$ & $\mathrm{SEM}_{\text {total }}$ & $P$ & $n^{\star}$ \\
\hline ADC of DM (\%) & $87 \cdot 2^{\mathrm{a}}$ & $87.9^{\mathrm{b}}$ & $90 \cdot 7^{\mathrm{c}}$ & $90 \cdot 3^{c}$ & 0.23 & $<0.001$ & 4 \\
\hline ADC of crude protein & $85 \cdot 4^{\mathrm{C}}$ & $84.5^{\mathrm{bc}}$ & $83 \cdot 4^{\mathrm{b}}$ & $79 \cdot 7^{\mathrm{a}}$ & 0.40 & $<0.001$ & 4 \\
\hline ADC of diethyl ether extract & $94 \cdot 8^{\mathrm{a}}$ & $95 \cdot 0^{\mathrm{a}}$ & $96 \cdot 1^{\mathrm{b}}$ & $96 \cdot 4^{\mathrm{b}}$ & 0.14 & $<0.001$ & 4 \\
\hline ADC of crude ash & $23 \cdot 0^{\mathrm{a}}$ & $30 \cdot 8^{b}$ & $42 \cdot 8^{\mathrm{c}}$ & $45 \cdot 6^{c}$ & $1 \cdot 34$ & $<0.001$ & 4 \\
\hline ADC of $\mathrm{N}$-free extract & $97 \cdot 4$ & $96 \cdot 9$ & 97.7 & $97 \cdot 5$ & 0.13 & 0.220 & 4 \\
\hline FEBPC (\% faecal DM) & $2 \cdot 67^{\mathrm{a}}$ & $2.99^{\mathrm{a}}$ & $3.98^{b}$ & $4 \cdot 60^{\mathrm{C}}$ & 0.14 & $<0.001$ & 4 \\
\hline FEBPC (\% faecal crude protein) & $13 \cdot 30^{\mathrm{a}}$ & $12 \cdot 85^{\mathrm{a}}$ & $15 \cdot 62^{b}$ & $15 \cdot 79^{b}$ & 0.35 & 0.002 & 4 \\
\hline FEBPC (\% crude protein intake) & $1.89^{\mathrm{a}}$ & $1 \cdot 86^{\mathrm{a}}$ & $2 \cdot 36^{\mathrm{b}}$ & $3 \cdot 14^{\mathrm{c}}$ & 0.09 & $<0.001$ & 4 \\
\hline Corrected ADC of crude protein (\%) & $87 \cdot 3^{\mathrm{b}}$ & $86 \cdot 4^{\mathrm{b}}$ & $86 \cdot 1^{\mathrm{b}}$ & $83 \cdot 2^{a}$ & 0.33 & $<0.001$ & 4 \\
\hline
\end{tabular}

$\mathrm{H}$, hydrolysed protein; L, intact protein; IN, $3 \%$ inulin.

$a, b, c$ Mean values within a row with unlike superscript letters were significantly different $(P<0.05)$.

* Number of repetitions within a treatment.

†For details of diets and procedures, see p. 937. 
Table 5. Haematology parameters†

(Mean values with their standard errors for sixteen dogs)

\begin{tabular}{|c|c|c|c|c|c|c|c|c|}
\hline Diet & $\mathrm{H}-\mathrm{IN}$ & $\mathrm{H}+\mathrm{IN}$ & $L-I N$ & $\mathrm{~L}+\mathrm{IN}$ & $\mathrm{SEM}_{\text {total }}$ & $P$ & $n^{*}$ & Reference values \\
\hline $\mathrm{Hb}(\mathrm{g} / \mathrm{l})$ & 169 & 165 & 167 & 165 & $1 \cdot 2$ & 0.715 & 4 & $140-200$ \\
\hline Packed cell volume (\%) & 49.5 & 48.5 & $49 \cdot 0$ & 48.5 & 0.34 & 0.668 & 4 & $43 \cdot 0-59 \cdot 0$ \\
\hline Leucocytes $(\times 1000 / \mu \mathrm{l})$ & $7 \cdot 1^{a}$ & $7 \cdot 4^{\mathrm{a}}$ & $7 \cdot 2^{\mathrm{a}}$ & $9 \cdot 4^{\mathrm{b}}$ & 0.34 & 0.044 & 4 & $6 \cdot 0-16 \cdot 0$ \\
\hline Segmentic neutrophils (\%) & $67 \cdot 8$ & $69 \cdot 0$ & $66 \cdot 4$ & $67 \cdot 3$ & 0.72 & 0.564 & 4 & $55 \cdot 0-77 \cdot 0$ \\
\hline Lymphocytes (\%) & $24 \cdot 1$ & $22 \cdot 7$ & $25 \cdot 7$ & $24 \cdot 6$ & 0.68 & 0.726 & 4 & $12 \cdot 0-35 \cdot 0$ \\
\hline Monocytes (\%) & $4 \cdot 3$ & $4 \cdot 7$ & $4 \cdot 7$ & $4 \cdot 8$ & 0.13 & 0.572 & 4 & $0 \cdot 0-10 \cdot 0$ \\
\hline Basophils (\%) & 0.49 & 0.42 & 0.51 & 0.47 & & 0.146 & 4 & $0-1$ \\
\hline Eosinophils (\%) & 3.3 & $2 \cdot 4$ & 2.6 & $2 \cdot 8$ & $0 \cdot 219$ & 0.812 & 4 & $0.0-8 \cdot 0$ \\
\hline Total segmentic neutrophils $(/ \mu \mathrm{l})$ & 5230 & 5037 & 4868 & 5259 & $165 \cdot 3$ & 0.812 & 4 & $3000-11500$ \\
\hline Total lymphocytes $(/ \mu \mathrm{l})$ & 1730 & 1858 & 1842 & 1917 & $62 \cdot 0$ & 0.726 & 4 & $1000-4800$ \\
\hline Total monocytes $(/ \mu \mathrm{l})$ & 331 & 348 & 346 & 373 & $14 \cdot 3$ & 0.778 & 4 & $<1350$ \\
\hline Total basophils $(/ \mu \mathrm{l})$ & 39 & 35 & 39 & 36 & & 0.299 & 4 & $0.0-80.0$ \\
\hline Total eosinophils $(/ \mu \mathrm{l})$ & 261 & 248 & 184 & 226 & & $0 \cdot 211$ & 4 & $<1250$ \\
\hline Thrombocytes $(\times 1000 / \mu l)$ & 385 & 387 & 375 & 386 & $11 \cdot 7$ & 0.983 & 4 & $164-510$ \\
\hline
\end{tabular}

$\mathrm{H}$, hydrolysed protein; L, intact protein; IN, $3 \%$ inulin.

${ }^{a, b}$ Mean values within a row with unlike superscript letters were significantly different $(P<0.05)$.

* Number of repetitions within a treatment.

†For details of diets and procedures, see p. 937.

faecal DM content (by lower DM digestibility). Fibre can increase faecal output ('bulking effect') by increasing faecal water, faecal DM (undegraded fibre residue), faecal bacterial biomass or a combination of these factors (Schneeman, 1987). The bulking effect of prebiotic supplementation is generally caused by a significant increase of faecal moisture, with effects varying with the type of prebiotic, degree of supplementation and type of diet used (Flickinger et al. 2003b; Hesta et al. 2003). Increased faecal water content can be associated with changes in water consumption or redistribution of water excretion, which depends on the physical water-holding properties of fibre and the osmotic effect of SCFA produced during fermentation (Schneeman, 1987). The significant decrease in faecal consistency score following IN supplementation in the present study was associated with increased faecal moisture content, but has no clinical importance because it remained in a range considered desirable and was not associated with excess water content or diarrhoea. In most of the studies reported, there were no significant changes in faecal consistency following prebiotic supplementation (Diez et al. 1998; Swanson et al. 2002a,b; Flickinger et al. 2003a). Softer faeces can be seen on higher concentrations of prebiotics; 6 and 9\% fructo-oligosaccharides (Hesta et al. 2001). In the present study, the lowest faecal scores were noted in the $\mathrm{H}+\mathrm{IN}$ group, which suggests a possible synergistic effect of IN and the hydrolysed protein. This could be explained by a shorter intestinal transit time (Mihatsch et al. 2001, 2005) or enhanced osmolarity of the hydrolysate. Vente-Spreeuwenberg et al. (2004) reported a decrease in faeces consistency of piglets fed protein hydrolysates compared with intact protein. In contrast, piglets weaned $2 \mathrm{~d}$ postpartum showed less diarrhoea on hydrolysed soya protein compared with intact soya protein or milk protein (McCracken et al. 1998) and no effect was seen following hydrolysis of casein on weanling pigs with diarrhoea (Hampson, 1986). There were no significant differences in faecal $\mathrm{pH}$ among treatments, yet a decreased intestinal $\mathrm{pH}$ by production of lactate and SCFA following fermentation of prebiotics in the colon is not always reflected in faecal $\mathrm{pH}$, probably

Table 6. Log-transformed serum total IgA, IgE, IgM and IgG concentrations and faecal total IgA concentrations† (Mean values with their standard errors for sixteen dogs)

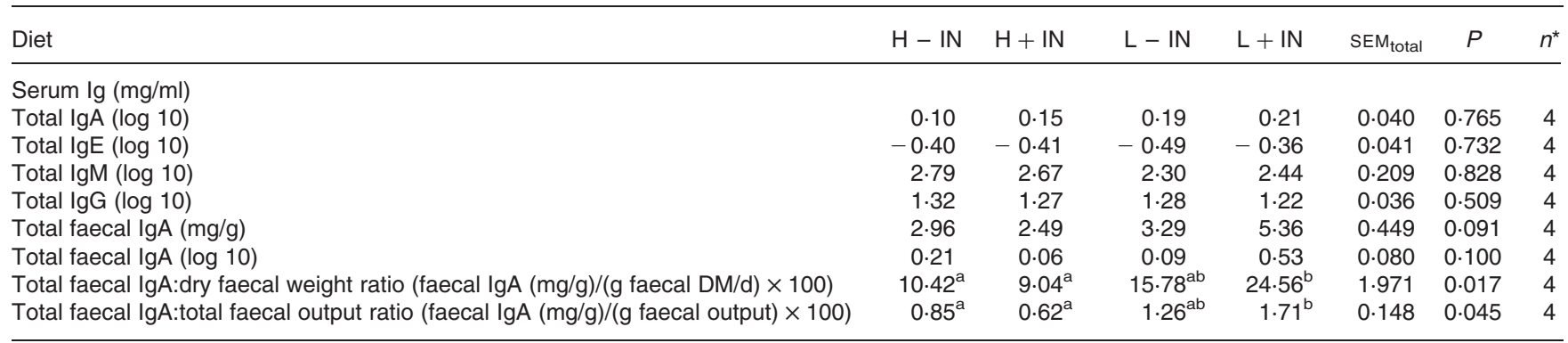

$\mathrm{H}$, hydrolysed protein; L, intact protein; IN, $3 \%$ inulin.

a,b Mean values within a row with unlike superscript letters were significantly different $(P<0.05)$.

* Number of repetitions within a treatment.

†For details of diets and procedures, see p. 937. 
due to rapid absorption of SCFA from the colon (Swanson et al. 2002b; Hesta et al. 2003).

\section{Apparent nutrient digestibility coefficients}

There was little influence of IN supplementation on nutrient ADC. On the H diet, IN supplementation caused only a slight increase in ADC of DM and crude ash, while on the L diet only a decrease in the apparent digestibility of crude protein was noticed. Results on the influence of prebiotic supplementation on apparent nutrient digestibility in dogs vary among studies, but despite changes in ADC, macronutrient availability for the dog is not reduced when supplementing low concentrations of prebiotics (Flickinger et al. 2003b). When comparing results on ADC among various experiments, the type of nondigestible oligosaccharide (short-chain fructo-oligosaccharides $v$. oligofructose and IN), its degree of supplementation and the composition of the diet used must be considered (Flickinger et al. 2003b; Van Loo, 2004). A decrease in nutrient digestibility can be explained by the higher water-binding capacity of the prebiotic, which influences the solubility of nutrients.

Decreased crude protein digestibility following prebiotic supplementation is often reported (Diez et al. 1998; Flickinger et al. 2003a; Hesta et al. 2003; Propst, 2003), but this is not the consequence of a lower true protein digestibility (Swanson et al. 2002b; Flickinger et al. 2003a; Propst, 2003), but related to the increase in faecal bacterial protein excretion (Hesta et al. 2001). Following correction for a higher faecal biomass, the apparent digestibility of crude protein is no longer decreased. However, in the present study, the difference in apparent digestibility of crude protein on the $\mathrm{L}-\mathrm{IN} v$. L + IN diet was still present following correction although less pronounced than before.

It is interesting to note that the ADC of crude protein was higher in the $\mathrm{H}$-fed dogs than the L-fed dogs. Pre-digestion by hydrolysis of the protein into smaller peptides and amino acids generally increases solubility, which results in improved digestibility (Boumans, 2001). Protein absorption in hydrolysed protein diets can occur both as peptides and amino acids. Several studies in human subjects and rats have shown that enzymic protein hydrolysates rich in di- and tripeptides have similar (Moriarty et al. 1985; Boza et al. 1995) or even higher (Poullain et al. 1989) nutritional values compared with those of their native proteins. This can be explained by a faster absorption rate of amino acids when the $\mathrm{N}$ source consists of small peptides rather than protein or free amino acids as demonstrated in rats (Monchi \& Rerat, 1993), pigs (Rerat et al. 1992; Yen et al. 2004) and human subjects (Ziegler et al. 1990; Collin-Vidal et al. 1994). However, we must acknowledge that the hydrolysation effect might have been confounded by differences in crude protein content and ingredient composition between the two diets. The lower crude protein content of the $\mathrm{L}$ diet $(14 \%)$ compared with the $\mathrm{H}$ diet $(18 \%)$ might have contributed to a slightly lower apparent digestibility of crude protein, as it can be hypothesised that endogenous protein losses remained unchanged. Future research is needed to determine the pure hydrolysation effect on the apparent digestibility of crude protein.

The present study shows a significantly lower ADC of crude ash in the $\mathrm{H}$ group. Despite the fact that the $\mathrm{H}$ and $\mathrm{L}$ diet differed in ingredients, it is known that protein hydrolysates can interfere with digestibility of minerals as demonstrated in infants (Rigo \& Senterre, 1994; Hernell \& Lönnerdal, 2003). However, prebiotics have a positive effect on digestibility of minerals in the dog (Beynen et al. 2002). Crude ash content was the same for all diets (see Table 1), but following IN supplementation, a significant increase in the ADC of crude ash was noticed only on the $\mathrm{H}$ diet.

\section{Faecal estimated bacterial protein content}

FEBPC expressed on DM basis, percentage of faecal crude protein or percentage of crude protein intake, was significantly lower in the $\mathrm{H}$ group compared with the L group. Differences in energy substrate supply for bacteria between the two diets can explain this finding. The average total dietary fibre and $\mathrm{N}$-free extract content of the L diet (5 and $62.9 \%$ respectively), were both higher compared with the $\mathrm{H}$ diet ( 3.5 and $61.4 \%$ respectively). This means that the substrate supply to the colonic microflora in dogs fed the L diet was higher, resulting in higher faecal biomass. However, it is important to note that as part of the total dietary fibre fraction, only soluble fibre contributes to bacterial substrate supply. To what extent the amount of soluble fibre between our diets was different was not fully determined, as the soluble dietary fibre analysis does not detect all soluble fibres. However, we can postulate that because of differences in ingredient composition between the two diets, the difference in fibre content is caused by the use of maize starch in the $\mathrm{H}$ diet and Brewer's rice in the L diet. Next to this, the cellulose content between both diets may be different. Subsequently, the higher amount of total dietary fibre in Brewer's rice $(2.1 \%$ $\mathrm{DM}$, of which $1.5 \%$ is insoluble fibre and $0.6 \%$ soluble fibre) compared with maize starch (0\% DM) (Bednar et al. 2001) contributes to higher FEBPC on the L diet. Protein digestibility also influences bacterial substrate availability; higher protein digestibility for the same amount of dietary protein means lower bacterial $\mathrm{N}$ supply and results in lower bacterial biomass. The apparent digestibility of crude protein in the $\mathrm{H}$ group was slightly higher compared with that in the L group, with also a significantly higher apparent digestibility of crude protein in the L - IN group compared with L + IN group. On the other hand, crude protein content of the $\mathrm{H}$ diet was higher than the $\mathrm{L}$ diet, leading to higher absolute bacterial $\mathrm{N}$ supply compared with the $\mathrm{L}$ diet. However, because differences in ileal digestibility between the diets are unknown we do not know the real protein supply to the colonic flora. Detection of faecal 'protein' must also be unknown, because conversion of undigested food protein into bacterial protein and its excretion in the faeces does not alter the detection of faecal 'protein'. Therefore, an increased urea flux into the large intestine can have served as an additional $\mathrm{N}$ source for the colonic microflora in the $\mathrm{L}$ group, resulting in a higher faecal biomass. IN supplementation only increased FEBPC (expressed on DM basis and crude protein intake) in the dogs fed the L diet. Differences in bacterial substrate supply (other than energy and $\mathrm{N}$ ) between the two diets because of differences in ingredient composition was probably the limiting factor for the lack of effect of IN on FEBPC on the $\mathrm{H}$ diet.

\section{Haematology}

The reason for the higher number of leucocytes on the $\mathrm{L}+\mathrm{IN}$ diet is unclear. This finding is in accordance with Grieshop et al. (2002), who compared supplementation of different 
concentrations of oral arabinogalactan with a control diet in dogs. The increased number of total leucocytes in their study was caused by a raise in neutrophils and eosinophils. In another study (Grieshop et al. 2004), lymphocytes decreased and neutrophils tended to increase following supplementation of chicory alone or in combination with mannanoligosaccharides. In contrast, supplementation of different prebiotics (Swanson et al. 2002b,c) had no effect on the total number of leucocytes. Only mannanoligosaccharide supplementation gave a higher number of lymphocytes, expressed as percentage of total number of leucocytes (Swanson, 2002b). However, the increase in leucocyte numbers has no clinical relevance as all the dogs remained healthy throughout the study period.

\section{Immunoglobulins}

IN supplementation had no effect on total serum IgA, IgE, IgM and $\mathrm{IgG}$ concentrations, which is in accordance with other studies in dogs (Grieshop et al. 2002, 2004; Swanson et al. $2002 b, c)$. However, this finding does not exclude a possible effect of IN on gut mucosal IgA concentrations because the concentration of $\operatorname{IgA}$ in the serum poorly correlates with that in mucosal secretions (German et al. 1998). Field et al. (1999) described a clear effect of fermentable fibre on gut-associated lymphoid tissue composition and function in dogs, although the effect was not detectable in the peripheral blood. However, because of practical and ethical issues, the measurement of serum Ig concentrations is one of the most commonly used assessments of immune competence in the dog.

IgA plays an important role in gastrointestinal immune responses and is locally produced by $\mathrm{IgA}^{+}$plasma cells within the lamina propria. Secretory $\operatorname{IgA}$ is formed when a part of the Ig receptor remains bound to the dimeric IgA, following transport of IgA across the epithelial barrier (Sampson, 1991). Secretory IgA inhibits the attachment and penetration of bacteria and toxins in the lumen, increases time for digestive enzymes to function, binds and prevents absorption of undigested proteins, increases mucus secretion and prevents inflammatory reactions (Russell et al. 1989; McKay \& Perdue, 1993). It is difficult to find an internal control molecule for comparison with Ig concentrations (Ferguson et al. 1995). The ideal internal control molecule would neither be affected by gut transit time, faecal DM or water content, nor be degraded by proteolytic enzymes. No such internal control has been identified in dogs to date. Therefore, faecal DM and total faecal output were used for normalisation, because the faecal DM was affected by the type of diet fed to the dogs. Total faecal IgA concentrations were influenced by the type of diet fed to the dogs, with lower values for the $\mathrm{H}$ diet compared with the $\mathrm{L}$ diet. This confirms the assumption of a real hypoallergenic hydrolysed protein diet, as increased faecal IgA concentrations indicate an attempt to protect the gut from the offending food. It has been shown that orally administered antigens increase Th2-type cytokine responses in Peyer's patches and induce the production of antigen-specific IgA by the intestinal mucosa (Xu-Amano et al. 1993; Yoshida et al. 2002). In infants, total faecal IgA levels increased during a challenge period in both cows' milk-allergic and non-allergic infants, indicating a diet change to one more antigenic (Saarinen et al. 2002). Hydrolysed protein consists of free amino acids and very short peptides and has reduced immunological reactivity. Data in human subjects indicate that proteins smaller than $10 \mathrm{kDa}$ are weakly immunogenic and peptides less than $2.5 \mathrm{kDa}$ are not immunogenic (Boumans, 2001). According to the manufacturer's label, the protein in the $\mathrm{H}$ diet is hydrolysed to a molecular weight less than $6 \mathrm{kDa}$ without intact protein, which represents a real hypoallergenic diet, in contrast with the L diet. Supplementation of IN had no significant effect on total faecal $\operatorname{Ig}$ A concentrations in the present study. This is in agreement with the study of Swanson et al. (2002b), where supplementing fructo-oligosaccharides and mannanoligosaccharides did not change faecal IgA concentrations in dogs, whilst ileal IgA concentrations were raised. Faecal IgA values were only $15 \%$ of that in ileal samples because of microbial breakdown in the colon. Therefore, it cannot be ruled out that we missed the effect of IN supplementation because of faecal sampling. However, there is a trend to higher total faecal $\operatorname{IgA}$ amounts on the L + IN compared with the other diets. In mice, increased faecal IgA concentrations were seen following fructo-oligosaccharide supplementation (Hosono et al. 2003). Also in rats, administration of non-digestible oligosaccharides enhanced IgA secretion in caecum and faeces (Kudoh et al. 1999; Roller et al. 2004). Different hypotheses exist on the mechanism of influence of prebiotics on the immune response; direct influence by a change of composition of the intestinal microflora and consecutive stimulation of the gut-associated lymphoid tissue (direct contact of the bacteria themselves or their microbial substances), or indirect effects by production of SCFA and modulation of mucin production (Schley \& Field, 2002).

\section{Conclusions}

Both IN supplementation and protein hydrolysation affected faecal production and apparent nutrient digestibilities, although differences in ingredient composition between the $\mathrm{H}$ and $\mathrm{L}$ diet may have confounded these effects. There were no effects on total serum Ig concentrations. Total faecal IgA concentrations were influenced by the protein source in the diet, with lower values on the $\mathrm{H}$ diet. To our knowledge the present report is the first to give immunological indications for the hypoallergenic aspect of a hydrolysed protein diet in dogs.

\section{Acknowledgements}

The present study was supported by the Special Research Fund of the Ghent University.

\section{References}

Bednar GE, Avinash RP, Murray SM, Grieshop CM, Merchen NR \& Fahey GC Jr (2001) Starch and fiber fractions in selected food and feed ingredients affect their small intestinal digestibility and fermentability and their large bowel fermentability in vitro in a canine model. J Nutr 131, 276-286.

Beynen AC, Baas JC, Hoekemeijer PE, Kappert HJ, Bakker MH, Koopman JP \& Lemmens AG (2002) Faecal bacterial profile, nitrogen excretion and mineral absorption in healthy dogs fed supplemental oligofructose. J Anim Physiol Anim Nutr 86, 298-305.

Boumans H (2001) Physiochemical and functional properties of protein hydrolysates in nutritional products. In Hill's European Symposium on Adverse Food Reactions, Symposium Proceedings, Madrid 2001, pp. 30-33. Watford, UK: Hill's Europe Publication. 
Boza JJ, Martinez-Augustin O, Baró L, Suarez MD \& Gil A (1995) Protein $v$. enzymic protein hydrolysates. Nitrogen utilization in starved rats. Br J Nutr 73, 65-71.

Collin-Vidal C, Cayol M, Obled C, Ziegler F, Bommelaer G \& Beaufrere B (1994) Leucine kinetics are different during feeding with whole protein or oligopeptides. Am J Physiol 267, E907-E914.

Diez M, Hornick JL, Baldwin P, van Eenaeme C \& Istasse L (1998) The influence of sugar-beet fibre, guar gum and inulin on nutrient digestibility, water consumption and plasma metabolites in healthy beagle dogs. Res Vet Sci 64, 91-96.

Ferguson A, Humphreys KA \& Croft NM (1995) Technical report: results of immunological tests on faecal extracts are likely to be extremely misleading. Clin Exp Immunol 99, 70-75.

Field CJ, McBurney MI, Massimino S, Hayek MG \& Sunvold GD (1999) The fermentable fibre content of the diet alters the function and composition of canine gut associated lymphoid tissue. Vet Immunol Immunopathol 72, 325-341.

Flickinger EA \& Fahey GC Jr (2002) Pet food and feed applications of inulin, oligofructose and other oligosaccharides. Br J Nutr 87, Suppl. 2, S297-S300.

Flickinger EA, Schreijen EMWC, Patil AR, Hussein HS, Grieshop CM, Merchen NR \& Fahey GC Jr (2003a) Nutrient digestibilities, microbial populations, and protein catabolites as affected by fructan supplementation of dog diets. J Anim Sci 81, 2008-2018.

Flickinger EA, Van Loo J \& Fahey GC Jr (2003b) Nutritional responses to the presence of inulin and oligofructose in the diets of domesticated animals: a review. Crit RevFood Sci Nutr 43, 19-60.

German AJ, Hall EJ \& Day MJ (1998) Measurement of IgG. IgM and IgA concentrations in canine serum, saliva, tears and bile. Vet Immunol Immunopathol 76, 25-43.

Gibson GR \& Roberfroid MB (1995) Dietary modulation of the human colonic microbiota: introducing the concept of prebiotics. J Nutr 125, 1401-1412.

Grieshop CM, Flickinger EA, Bruce KJ, Patil AR, CzarneckiMaulden GL \& Fahey GC Jr (2004) Gastrointestinal and immunological responses of senior dogs to chicory and mannanoligosaccharides. Arch Anim Nutr 58, 483-493.

Grieshop CM, Flickinger EA \& Fahey GC Jr (2002) Oral administration of arabinogalactan affects immune status and fecal microbial populations in dogs. J Nutr 132, 478-482.

Hampson DJ (1986) Attempts to modify changes in the piglet small intestine after weaning. Res Vet Sci 40, 313-317.

Hernell O \& Lönnerdal B (2003) Nutritional evaluation of protein hydrolysate formulas in healthy term infants: plasma amino acids, hematology, and trace elements. Am J Clin Nutr 78, 289-301.

Hesta M, Janssens G, Debraekeleer J \& De Wilde R (2001) The effect of oligofructose and inulin on faecal characteristics and nutrient digestibility in healthy cats. J Anim Physiol Anim Nutr 85, 135-141.

Hesta M, Roosen W, Janssens GPJ, Millet S \& De Wilde R (2003) Prebiotics affect nutrient digestibility but not faecal ammonia in dogs fed increased protein levels. Br J Nutr 90, 1007-1014.

Hosono A, Ozawa A, Kato R, Ohnishi Y, Nakanishi Y, Kimura T \& Nakamura R (2003) Dietary fructooligosaccharides induce immunoregulation of intestinal IgA secretion by murine Peyer's patch cells. Biosci Biotechnol Biochem 67, 758-764.

Isolauri E (2001) Probiotics in the prevention and treatment of allergic disease. Pediatr Allergy Immunol 12, Suppl. 14, 56-59.

Jeffers JG, Shanley KJ \& Meyer EK (1991) Diagnostic testing of dogs for food hypersensitivity. JAVMA 198, 245-250.

Kudoh K, Shimizu J, Ishiyama A, Wada M, Takita T, Kanke Y \& Innami S (1999) Secretion and excretion of immunoglobulin A to cecum and feces differ with type of indigestible saccharides. J Nutr Sci Vitaminol 45, 173-181.

Loeffler A, Lloyd DH, Bond R, Kim JY \& Pfeiffer D (2004) Dietary trials with commercial chicken hydrolysate diet in sixty-three pruritic dogs. Vet Rec 154, 519-522.
McCracken BA, Zijlstra RT, Donovan SM, Odle J, Lien EL \& Gaskins HR (1998) Neither intact nor hydrolysed soy proteins elicit intestinal inflammation in neonatal piglets. JPEN-Parenter Enter 22, 91-97.

McKay DM \& Perdue MH (1993) Intestinal epithelial function: the case for immunophysiological regulation. Dig Dis Sci 38, $1377-1387$.

Mahmoud MI (1994) Physicochemical and functional properties of protein hydrolysates in nutritional products. Food Technol 48, 89-95.

Mason VC (1969) Some observations on the distribution and origin of nitrogen in sheep faeces. J Agr Sci 73, 99-111.

Mihatsch WA, Franz AR, Kuhnt B, Hogel J \& Pohlandt F (2005) Hydrolysis of casein accelerates gastrointestinal transit via reduction of opioid receptor agonists released from casein in rats. Biol Neonate 87, 160-163.

Mihatsch WA, Högel J \& Pohlandt F (2001) Hydrolysed protein accelerates the gastrointestinal transport of formula in preterm infants. Acta Paediatr 90, 196-198.

Monchi M \& Rerat AA (1993) Comparison of net protein utilization of milk protein mild enzymatic hydrolysates and free amino acid mixtures with a close pattern in the rat. J Parenter Enteral Nutr 17, 355-363.

Moriarty KJ, Hegarty JE, Fairclough PD, Kelly MJ, Clark ML \& Dawson AM (1985) Relative nutritional value of whole protein, hydrolysed protein and free amino acids in man. Gut 26, 694-699.

Moro GE, Stahl B, Fanaro S, Jelinek J, Boehm G \& Coppa GV (2005) Dietary prebiotic oligosaccharides are detectable in the faeces of formula-fed infants. Acta Paediatr 94, Suppl., 27-30.

Niness KR (1999) Inulin and oligofructose: what are they? J Nutr 129, $1402 \mathrm{~S}-1406 \mathrm{~S}$.

Poullain MG, Cezard JP, Roger L \& Mendy F (1989) Effect of whey proteins, their oligopeptide hydrolysates and free amino acid mixtures on growth and nitrogen retention in fed and starved rats. J Parenter Enteral Nutr 13, 382-386.

Propst EL, Flickinger EA, Bauer LL, Merchen NR \& Fahey GC Jr (2003) A dose-response experiment evaluating the effects of oligofructose and inulin digestibility, stool quality, and fecal protein catabolites in healthy adult dogs. J Anim Sci 81, 3057-3066.

Rerat A, Simoes-Nunes C, Mendy F, Vaissade P \& Vaugelade P (1992) Splanchnic fluxes of amino acids after duodenal infusion of carbohydrate solutions containing free amino acids or oligopeptides in the non-anaesthetized pig. $B r J$ Nutr 68, $111-138$.

Rigo J \& Senterre J (1994) Metabolic balance studies and plasma amino acid concentrations in preterm infants fed experimental protein hydrolysate preterm formulas. Acta Paediatr 405, 98-104.

Roller M, Rechkemmer G \& Watzl B (2004) Prebiotic unulin enriched with oligofructose in combination with the probiotics Lactobacillus rhamnosus and Bifidobacterium lactis modulates intestinal immune functions in rats. J Nutr 134, 153-156.

Roudebush P \& Cowell CS (1992) Results of a hypoallergenic diet survey of veterinarians in North America with a nutritional evaluation of homemade diet prescriptions. Vet Dermatol 3, 23-28.

Roudebush P \& Schick RO (1994) Evaluation of a commercial canned lamb and rice diet for the management of adverse reactions to food in dogs. Vet Dermatol 5, 63-67.

Russell MW, Reinholdt J \& Killian M (1989) Anti-inflammatory activity of human IgA antibodies and their Fab $\alpha$ fragments:inhibition of IgG-mediated component activation. Eur J Immunol 19, $2243-2249$.

Saarinen KM, Sarnesto A \& Savilahti E (2002) Markers of inflammation in the feces of infants with cow's milk allergy. Pediatr Allergy Immunol 13, 188-194.

Sampson HA (1991) Immunologic mechanisms in adverse reactions to foods. Immunol Allergy Clin North Am 11, 701-716. 
Schley PD \& Field CJ (2002) The immune-enhancing effects of dietary fibres and prebiotics. Br J Nutr 87, Suppl. 2, S221-S230.

Schneeman B (1987) Dietary fiber and gastrointestinal function. Nutr Rev 45, 129-132.

Swanson KS, Grieshop CM, Flickinger A, Bauer LL, Chow J, Wolf BW, Garleb KA \& Fahey GC (2002a) Fructooligosachharides and Lactobacillus acidophilus modify gut microbial populations, total tract nutrient digestibilities and fecal protein catabolite concentrations in healthy adult dogs. J Nutr 132, 3721-3731.

Swanson KS, Grieshop CM, Flickinger A, Bauer LL, Healy HP, Dawson KA, Merchen NR \& Fahey GC Jr (2002b) Supplemental fructooligosaccharides and mannanoligosaccharides influence immune function, ileal and total tract nutrient digestibilities, microbial populations and concentrations of protein catabolites in the large bowel of dogs. J Nutr 132, 980-989.

Swanson KS, Grieshop CM, Flickinger A, Merchen NR \& Fahey GC $\mathrm{Jr}$ (2002c) Effects of supplemental fructooligosaccharides and mannanoligosaccharides on colonic microbial populations, immune function and fecal odor components in the canine. $J$ Nutr 132, 1717S-1719S.

Van Loo J (2004) The specificity of the interaction with intestinal bacterial fermentation by prebiotics determines their physiological efficacy. Nutr Res Rev 17, 89-98.

Veereman-Wauters G (2005) Applications of prebiotics in infant foods. Br J Nutr 93, Suppl. 1, S57-S60.

Vente-Spreeuwenberg MAM, Verdonk JMAJ, Koninkx JFJG, Beynen AC \& Verstegen MWA (2004) Dietary protein hydrolysates $v s$. the intact proteins do not enhance mucosal integrity and growth performance in weaned piglets. Livestock Prod Sci 85, 151-164.

Viljanen M, Kuitunen M, Haahtela T, Juntunen-Backman K, Korpela R \& Savilahti E (2005) Probiotic effects on faecal inflammatory markers and on faecal $\operatorname{IgA}$ in food allergic atopic eczema/dermatitis syndrome infants. Pediatr Allergy Immunol 16, 65-71.

Xu-Amano J, Kiyono H, Jackson RJ, Staats HF, Fujihashi K, Burrows PD, Elson CO, Pillai S \& McGhee JR (1993) Helper $\mathrm{T}$ cell subsets for immunoglobulin A responses: oral immunization with tetanus toxoid and cholera toxin as adjuvant selectively induces Th2 cells in mucosa associated tissues. $J$ Exp Med 178, 1309-1320.

Yen JT, Kerr BJ, Easter RA \& Parkhurst AM (2004) Difference in rates of net portal absorption between crystalline and proteinbound lysine and threonine in growing pigs fed once daily. J Anim Sci 82, 1079-1090.

Yoshida T, Hachimura S, Ishimori M, Kinugasa F, Ise W, Totsuka M, Ametani A \& Kaminogawa S (2002) Antigen presentation by Peyer's patch cells can induce both Th1- and Th2-type responses depending on antigen dosage, but a different cytokine response pattern from that of spleen cells. Biosci Biotechnol Biochem 66, 963-969.

Ziegler F, Ollivier JM, Cynober L, Masini JP, Coudray-Lucas C, Levy E \& Giboudeau J (1990) Efficiency of enteral nitrogen support in surgical patients: small peptides $v$. non-degraded proteins. Gut 31, 1277-1283. 